\title{
Children Immigration in the Catalan Parliamentary Debate: The Empty Set
}

MARTA POBLET, JOAN-JOSEP VALLBÉ

UNIVERSIDAD AUTÓNOMA DE BARCELONA

ABSTRACT: Catalonia has received an unprecedented number of unaccompanied foreign children throughout the past decades, most of them from Morocco. This new form of migration has had a significant effect on the way that Children Welfare Services in Catalonia have been rearranged at different levels. Yet, the administrative reforms were not matched by a parallel substantive debate in Parliament. By analyzing a textual corpus of parliamentary texts, the article concludes that the set of parliamentary activities covering the issue of unaccompanied children contains no elements to ground a substantial political debate around it.

Keywords: Migration, unaccompanied children, administrative reform, textual analysis, political debate.

RESUMEN: Cataluña ha recibido un número sin precedentes de menores no acompañados durante las últimas décadas, la mayoría de ellos procedentes de Marruecos. Esta nueva forma de migración ha tenido un impacto significativo en la posterior reorganización de los Servicios de Atención a la Infancia en Cataluña. Sin embargo, las reformas administrativas se llevaron a cabo sin un debate paralelo de fondo en el Parlamento. Mediante el análisis de un corpus textual de los textos parlamentarios, el artículo concluye que el conjunto de las actividades parlamentarias relacionadas con la llegada de menores no acompañados carece de los elementos que permiten generar un debate político de fondo.

Palabras clave: migración, menores no acompañados, reforma administrativa, análisis textual, debate político. 


\section{Introduction}

In recent years, Catalonia has received an unprecedented number of unaccompanied foreign children, most of them of Moroccan origins. While this new form of migration has had a significant effect on the way that Children Welfare Services in Catalonia have been rearranged at different levels, it seems also to be the case that administrative reforms have taken place without a parallel substantive debate in Parliament. In this article we use the metaphor of «the empty set» to describe parliamentary activities as a set with no elements inside it, and we extend it as to consider parliamentary discourse patterns regarding children immigration as «vacuously truth» statements, since parliamentary consensus tends to hold discourses true without being necessarily related to parallel administrative reforms.

To illustrate the metaphor, we first show how changes occurred at the administrative level, and even how this issue had some coverage in the media. Secondly, we turn our attention to a textual corpus of parliamentary texts that serves to characterize the political debate. To this end, we have collected a corpus of parliamentary texts and split it into four sub-corpora depending on the parliamentary activity that they represent: debates; written pairs of parliamentary questions and answers to the Government; parliamentary motions and resolutions; and reports of the Catalan ombudsman submitted to the Parliament, followed by statements of all the parliamentary groups. These sub-corpora are analyzed using computer-assisted text analysis techniques, which allow for the identification, representation, and interpretation of the salience of the most relevant parliamentary discourse patterns. With this analysis, we aim at exploring the process through which issues remain politically underdeveloped and in a prepolitical stage of agenda-setting dynamics (Jones \& Baumgartner, 2004).

For the purpose of this work we adopt a standard definition of unaccompanied or separated minors, such as «children under 18 years of age who are outside their country of origin and separated from their parents or their previous legal/customary primary caregiver» (UNHCR, 1997; SCEP, 2004). While some European countries (e.g., France) had traditionally received minors escaping persecution or human rights abuse, the young migrants of the nineties especially those North-African children reaching Euro-Mediterranean countries flee from growing economic imbalances between riparian states, seeking not necessarily asylum but what is perceived as a better future prospect in more developed countries. Separated children from North-African countries often refer to themselves as «harrag», metaphorically meaning «those who burn their documents to improve their life conditions in Europe» (Quiroga, 2003). ${ }^{1}$

1. As the same author indicates, harrag (pl. harraga) is the dialectal deformation of the Classical Arabic root $h r q$, meaning «to burn», «to set fire» (Quiroga, 2003). 
Below we begin with a contextualization of the situation of MEINA in Catalonia, regarding both their basic facts (section 2) and their legal status (section 3). In section 4 we present and discuss the main administrative reforms covering the reception and situation of MEINA in Catalonia during the period 1998-2006. Section 5 presents our research questions, data, and methodology. Results are presented in section 6, while the last section is devoted to the conclusions and discussion.

\section{Contextual Information}

The presence of the young harraga in Europe is already evident by the mid nineties. Many European countries register significant increases in the period 1996-2000 (e.g., more than 130\% in Italy and Switzerland) (CONRED, 2003). In 1997, the Eu Council issued a Resolution to establish guidelines for the treatment of unaccompanied minors regarding matters such as the conditions for their reception, stay and return, and, in the case of asylum seekers, the handling of applicable procedures. ${ }^{2}$ The Resolution was followed by the Eu Directive of 27 January 2003, urging to provide comparable reception standards to asylum seekers and setting out a range of safeguards for separated children, including representation by legal guardianship, appropriate accommodation, family tracing, and training for those working with separated children. However, the directive was severely criticized by several non-governmental organizations, for it did not exclude the possibility of children being held in detention, which is contrary to the 1997 UNHCR provision (Ruxton, 2000). This and other particular points (e.g., should minors over 16 years of age be held in centers for adults; setting up priorities regarding return policies and procedures; the use of biometric data to obtain accurate identification of children; etc.) are currently in the center of political debate in Europe.

Generally, European countries have deployed two models of dealing with illegal entries of minors: through policies applying to asylum seekers, or through legislation protecting children (CONRED, 2003). ${ }^{3}$ The first model - e.g., Belgium, Denmark, Ireland, Portugal, and Switzerland - makes the condition of asylum seeker to prevail over minority, while the second - Spain and Italy - considers unaccompanied children first as «minors in risk situation» who are eligible for protective measures by the administrative authorities, and only afterwards

2. Council Resolution of 26 June 1997 on unaccompanied minors who are nationals of third countries (97/C 221/03).

3. France, however, constitutes a good example of a mixed model, since it applies either asylum legislation or minors' legislation depending on the space where the children are intercepted: the country's borders or inside the national territory (CONRED, 2003). 
asylum policies apply. Nevertheless, as we will see below, ad hoc return policies may contradict this protective model.

In Spain, children immigration went almost unnoticed until the late nineties, the very first cases being detected by 1998. Typical unaccompanied children were primarily 14-17 year-old boys from Morocco who reached the peninsula stowing-away under a truck or on small boats (pateras or cayucos) that trafficking mafias bound to the South-eastern coasts of Andalusia or, more recently, westward to the Canary Islands. Although figures for unaccompanied children are usually controversial, Catalonia is one of the areas typically attracting a major number of minors, together with Madrid, Andalusia, and the Basque Country. In 2002, one out of four unaccompanied children in Spanish soil was registered by the Child Protective Services of the Catalan Government $(1,659$ out of 6,329). Regarding their origin, 94 percent of them came from Morocco (and, within this group, more than 50 percent from the city of Tangier), 4.6 percent from Algeria, 1.9 percent from other countries, and the remaining 1.5 percent had unknown origins. As regards gender, an overwhelming majority of them (97 percent) were male. Further research (Capdevila \& Ferrer, 2003) pointed to the following trends:

- The average age of unaccompanied children in Catalonia at their arrival is 15.7 years-old.

- 80.2 percent of children have not broken their family links back in Morocco.

- On average, children belong to families composed of 6-10 members.

- Family income is low (only one member of the family has a paid job, but it is usually a discontinuous and unskilled job).

- Children usually withdraw from school at the age of 14-17 years-old to support the family economy (19.7 percent of them are illiterate). Once they perceive that they fail to contribute to the family income they start thinking of migrating.

- 50 percent of children have relatives who have previously migrated to Europe (41.2 percent being elder brothers), the most usual destinations of elders being Spain, France, Italy and Belgium.

- 77.2 percent of families agree with children's intention to leave the country, even though they were not an active part in their travel plans. In Spain, 99 percent of minors keep regular telephone contact with their parents and families.

In 2005 the NGO SOS Racismo issued a report on a sample of Moroccan unaccompanied children in Spain (sos Racismo, 2005). ${ }^{4}$ A basic sociological

4. The report was based on a sample of 28 interviews with Moroccan children that, due to a systematic lack of official data on the issue, were carried out by members of that organization. The authors of the report acknowledge that the sample may be unrepresentative of the population. 
profile of this group of Moroccan children at the Spanish level does not significantly differ from that elaborated in Catalonia, as shown in table 1 and figures 1 and 2 .

Table 1. Family attitudes and situation of unaccompanied minors in Spain. Source: sos Racismo (2005)

\begin{tabular}{|l|l|l|}
\hline Features of MEINA's families & \multicolumn{2}{|l|}{ Percentage $(N=28)$} \\
\hline & Yes & No \\
\hline Did the family know that the child was to emigrate? & 57 & 43 \\
\hline Did the family support the child's emigration? & 35 & 65 \\
\hline Members of the family had already emigrated & 65 & 35 \\
\hline
\end{tabular}

Finally, 84.5 percent of unaccompanied children in Catalonia reported finding a job as their main reason for migrating. However, since Spanish legislation establishes the age of 16 as the legal age to enter the job market, this framework leads to disruptive situations with the Child Protective Services. As a result, minors may also be discontinuously inside and outside the protective system.
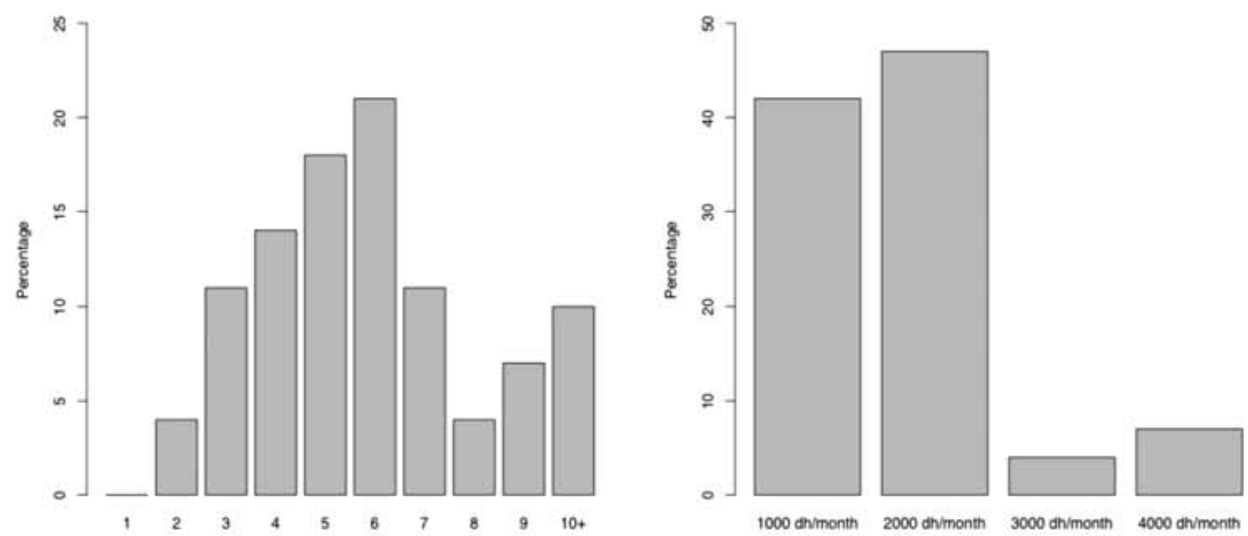

Figure 1. Demographic and economic conditions of unaccompanied minors' families. The left panel shows the number of children per family unit and the percentage of each category of family among unaccompanied children. The right panel shows the unbalanced distribution of income among these families, in which most families present low levels of income. $(\mathrm{N}=28)$.

Source: sos Racismo (2005) 

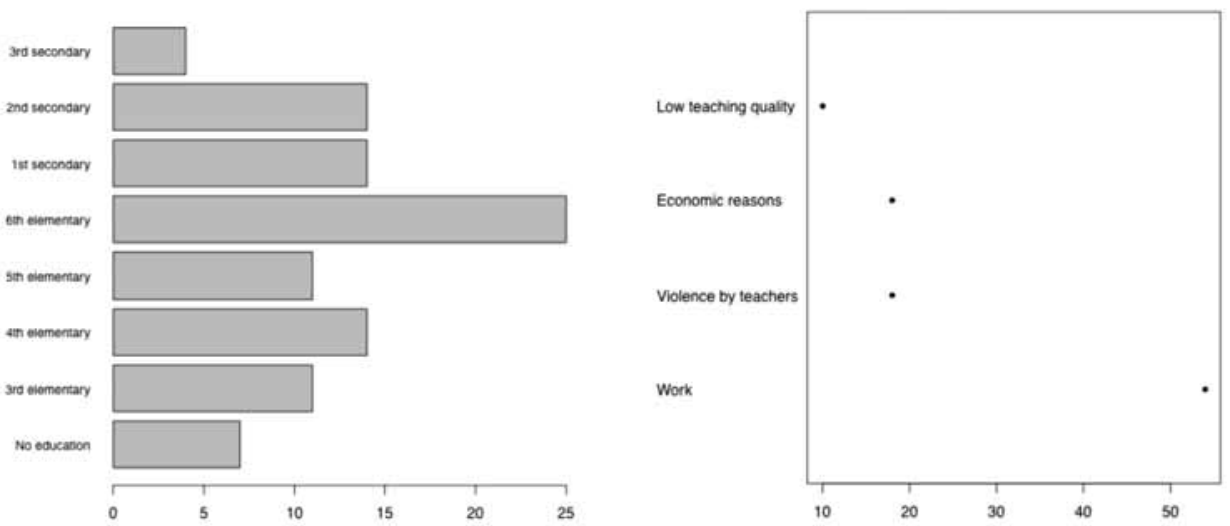

Figure 2. Education level and reasons that led unaccompanied minors to abandon formal education in Morocco. The left panel shows the percentage of children in each last educational level achieved in Morocco. The right panel shows the declared reasons why these children abandoned their formal education. (N=28). Source: sos Racismo (2005)

\section{Legal Rights and Procedures}

In Spain, unaccompanied children in the territory are considered to be in a state of helplessness («desamparo»), which requires the immediate assumption of the child's legal guardianship by the government. 5 This legal framework, nevertheless, was challenged in 2003 in two different directions: first, the Public Prosecutor Instruction 3/2003 of October $27^{\text {th }}$, urging to return within 48 hours to Morocco those unaccompanied children over the age of 16 detected in the territory; ${ }^{6}$ and, second, the December 8, 2003 Memorandum of Agreement between Spain and Morocco, which also makes it possible to repatriate minors to Morocco. The Instruction was reversed by the appointment of a new General Prosecutor in 2004,7 and the Memorandum renewed by the Accord entre le Royaume du Maroc et le Royaume d'Espagne sur la coopération dans le domaine de la prévention de l'emigration illégale de mineurs non accompagnés, leur protection et leur retour concerté of May 6, 2007. The use of these two high-level government instruments indicates the extent to which unaccompanied children are seen as a major policy problem facing public authorities.

5. Article 239 of the Civil Code establishes that public authorities shall assume the guardianship of minors in a helplessness situation. See also the 1/96 Legal Protection of Minors Act and the 5/1984 Asylum Act.

6. The main argument being that unaccompanied children over 16 years old could de facto been considered as emancipated minors for whom the protective system is not applicable anymore.

7. Public Prosecutor Instruction 6/2004 of November 26th. 
The first step for a child accessing the child welfare services is to obtain the legal declaration of helplessness as a prerequisite for guardianship («tutela»). ${ }^{8}$ Guardianship is an official document formally recognizing that the relevant authorities have accepted the responsibility to protect the child. In Spain, the governments of the autonomous communities where a child is detected have the authority and thus the legal obligation to address this issue (usually through the child welfare authorities). In the meantime, custody of the child is subsequently transferred to the director of the centre with responsibility for the child's care.

Table 2. Characteristics of return of unaccompanied children to Morocco.

Source: sos Racismo (2005)

\begin{tabular}{|l|l|l|}
\hline Features of children returns & \multicolumn{2}{|l|}{ Percentage $(N=28)$} \\
\hline & Yes & No \\
\hline Did the family know that the child was to emigrate? & 57 & 43 \\
\hline Does the child want to return? & 0 & 100 \\
\hline Is the child let to talk as specified by article 9 of LOPJM? & 0 & 100 \\
\hline Is the child's family informed about the child's return & 7 & 93 \\
\hline $\begin{array}{l}\text { Does the child suffer any risk or deterioration of his/her } \\
\text { physical conditions during the return, as specified } \\
\text { in art. 92.4 RD 2393/04? }\end{array}$ & 100 & 0 \\
\hline Has the child tried to migrate again? & 100 & 0 \\
\hline Has the child gone back to Spain? & 21 & 79 \\
\hline Is the child being tried in Morocco? & 29 & 71 \\
\hline Must the child pay a fine? & 7 & 93 \\
\hline
\end{tabular}

Once the authorities have legally assumed the guardianship of the minor, the next steps in the process of integration - access to education and later applying for work and residence permits - are made much easier. However, many difficulties arise at this point. The Spanish legislation establishes a nine-month deadline to assume the guardianship of the child and gather all relevant

8. The procedure goes as follows: «The DGAIA [Catalan Child Protection Services] interviews all children that have no papers or other types of identification. When interviewed the DGAIA seeks to determine where the minor came from, why he came and how. The police also perform an assessment of the minor's age using bone age estimation by radiology. After the first interviews the DGAIA contacts the child's family and compares the information the child gave with information from the family. They try to establish whether the child has migrated with or without parental consent. The children normally agree to give the contact details of the parents, since they are told that the Spanish authorities need the authorisation of the father (emancipation de facto) in order to give the child the Tutela» (Hjort Hansen, 2005). 
documents needed to apply for residence and work permits. ${ }^{9}$ But in many autonomous communities such as Catalonia, Madrid or the Canary Islands children may reach the age of 18 without any legal documents and are expelled from the protection system with little opportunities to obtain their legal residence or find a job. This situation entails a risk of immediate social exclusion for children that have developed well-based expectations to legalize their situation.



Figure $3 A$. Number of returns accumulated by returned children



Figure 3B. Ways through which unaccompanied children return to Morocco
Figure 3C. How returned children feel on their return

Figure 3. Different ways of observing children returns to Morocco. The figure on the left presents the picture of repeated attempts to migrate from Morocco to Spain. The $\mathrm{x}$-axis represents the number of returns applied to a child (up to 8 returns), and the y-axis represents the percentage of children for each number of returns. The figure in the middle represents the three different ways through which children were returned to Morocco in 2005. The figure on the right panel represents the feelings among the returned children. $(\mathrm{N}=28)$. Source: sos Racismo (2005)

If guardianship is the entrance door to welfare services, the procedures of return or repatriation to the country of origin are their backdoor. Generally, international conventions, legislation, and recommendations establish that return to the country of origin may only be arranged if such return is in the best interest of the child and some basic conditions are fulfilled. ${ }^{10}$ While both the Spanish and

9. Article 92.5 of the Reglamento de la Ley Orgánica de la Ley de Extranjería 4/2000 (Real Decreto 2393/2004 of December 30th).

10. See, for instance, Council Resolution of 26 June 1997, supra note 2. See also the 1989 United Nations Convention on the Rights of the Child and the 2005 General Comment 6 adopted by the UN Committee on the Rights of the Child on treatment of unaccompanied and separated children outside their country of origin. In the three cases the «best interests of the child» prevails as the overarching principle when considering return policies. More specifically, the General Comment 6 recommends to take into account: (i) The safety, security and other conditions, including socio-economic conditions, awaiting the child upon return, including through home study, where appropriate, conducted by social network organizations; (ii) The availability of care arrangements for that particular child; (iii) The views of the 
Catalan legislations establish the «best interest of the child» as the overarching principle to take into account in developing public policies for minors, it is also true that specific legislation on alien citizens considers the principle of family reunification as the basis for procedures of return. ${ }^{11}$ Even though cases of minors' returns had not reached big figures at the time our analysis applies (15 cases in 2004 and 18 in 2005 in Catalonia), the procedures have been highly contested by NGOS and Spanish Ombudsmen alike for violating both international conventions and internal legal provisions. ${ }^{12}$ In the 2005 sos Racismo inquiry on 28 cases of return of children to Morocco, the organization reported that none of the children wished to return, and, except in two cases, families were not consulted (as established by the Spanish legislation). The report also notes that upon return some children were abused by the police, imprisoned, and had to pay for their release (sos Racismo, 2005). Table 2 and the three panels of Figure 3 show some features of those 28 return proceedings according to this NGO investigation.

\section{Media Coverage and Administrative Rearrangements}

The presence of unaccompanied children in Catalonia was first made visible by the media. As Quiroga has recalled, between May 1998 and December 1999 the media in Catalonia produced 78 pieces of news in press (articles, reports) and TV (documentaries) that she classifies as follows: (1) alerts of the arrival of unaccompanied children; (2) description of the migration process, including some life stories; (3) news of minors refusing children protection services; (4) articles including the perspective of NGOS and civil society; (5) articles criminalizing unaccompanied minors (by associating them to small delinquency). Generally, according to Quiroga, the media coverage of unaccompanied children contributed to generate an early state of alarm since it tended to relate this new presence of minors to street living - these children are usually referred to as «street children»drug trafficking, and petty crime (Quiroga, 2003).

child expressed in exercise of his or her right to do so under article 12 [of the 1989 Convention] and those of the caretakers; (iii) The child's level of integration in the host country and the duration of absence from the home country; (iv) The child's right «to preserve his or her identity, including nationality, name and family relations» (art. 8 of the Convention); and (v) The «desirability of continuity in a child's upbringing and to the child's ethnic, religious, cultural and linguistic background» (art. 20 of the Convention).

11. See article 35.3 of the $8 / 2000$ Act of Rights and Freedoms of foreign citizens in Spain, and article 62.4 of the Regulation developing the 8/2000 Act (Royal Decree 864/2001 of July 20th).

12. See Defensories de l'Estat (2006), Defensor del Pueblo (2005), and Síndic de Greuges de Catalunya (2006). 


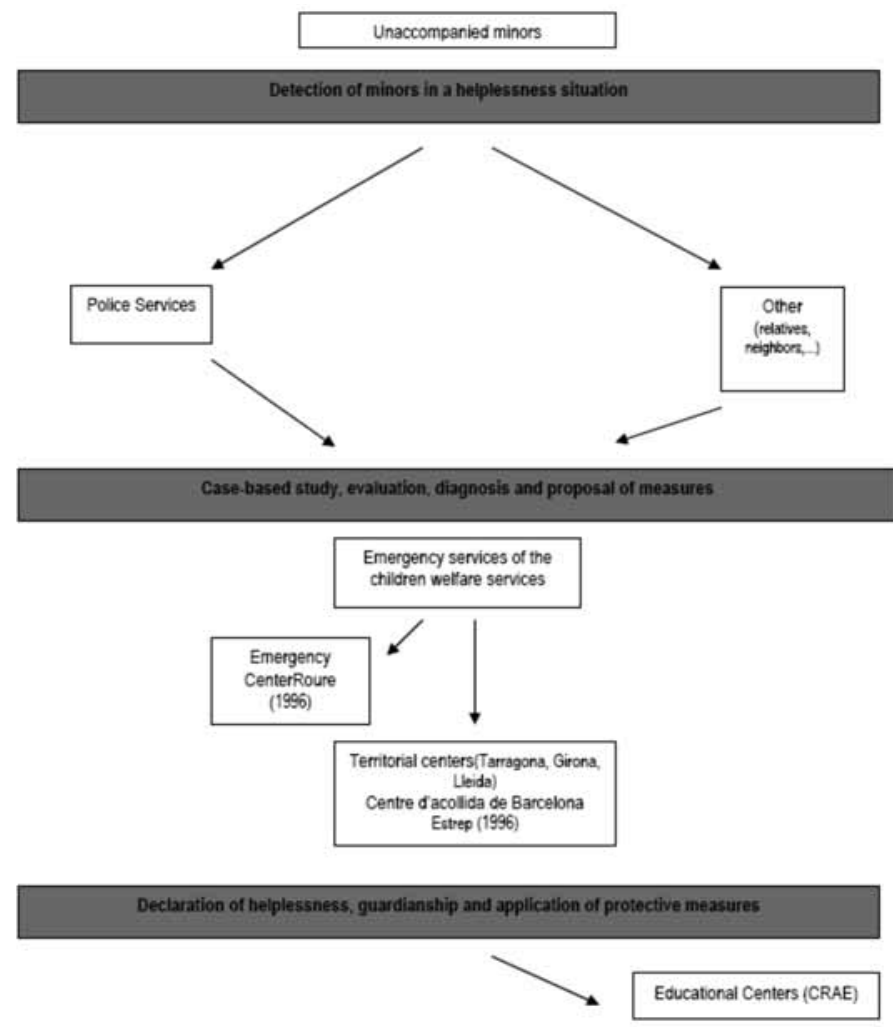

Figure 4. Catalan Children Protection Services in 1998.

Source: Quiroga (2003)

Public debate in the media runs parallel to the adoption of administrative measures. Thus, in September 1998 the Children Protective Services and the Justice Department of the Catalan Government organized a permanent round table to evaluate the situation and coordinate policies. Participants also included the Home Office Department of the Catalan Government, the Delegation of the Spanish Government in Catalonia, the city councils of Barcelona and Santa Coloma de Gramenet, the Public Prosecution Office, the Catalan Ombudsman, and the autonomic, national, and local police departments operating in Catalonia. As the Catalan Ombudsman reported:

Discussions made the novelty and seriousness of the situation apparent. It was honestly acknowledged that present resources did not match actual needs, and if government was to act as a father this would require putting in place adequate means. It was also agreed that educative intervention was the correct discourse, and if children did not want to be sent to protective centers they did not fit in borstal centers either (Síndic de Greuges, 1999). 
The quotation nicely echoes the administrative discourse of the era: the administrative authorities are dealing with an unprecedented phenomenon that challenges their present capacities «to act as a father» (the administrative reverse of the «best interest of the child» principle) and thus calls for urgent intervention and organizational rearrangement. To some extent, the discourse also anticipates the policies adopted in the years to come. Shortly after these initial meetings, the institutions involved in the round table issued an «Agreement of coordination and compromise to improve the inter-institutional response to the social problem of undocumented minors' immigration with a high social risk» (May 9, 1999). Undocumented minors would soon be labeled as MEINA (the Catalan acronym of «unaccompanied, undocumented foreign minors») and would usually be associated with a situation of «high social risk». Consequently, institutional rearrangements would consist of creating new emergency centers or making agreements with non-profit organizations to provide children with shelter and educational programs. As a result, the institutional landscape of children protection services in Catalonia transformed in just three years, as showed in figures 4 and 5 .

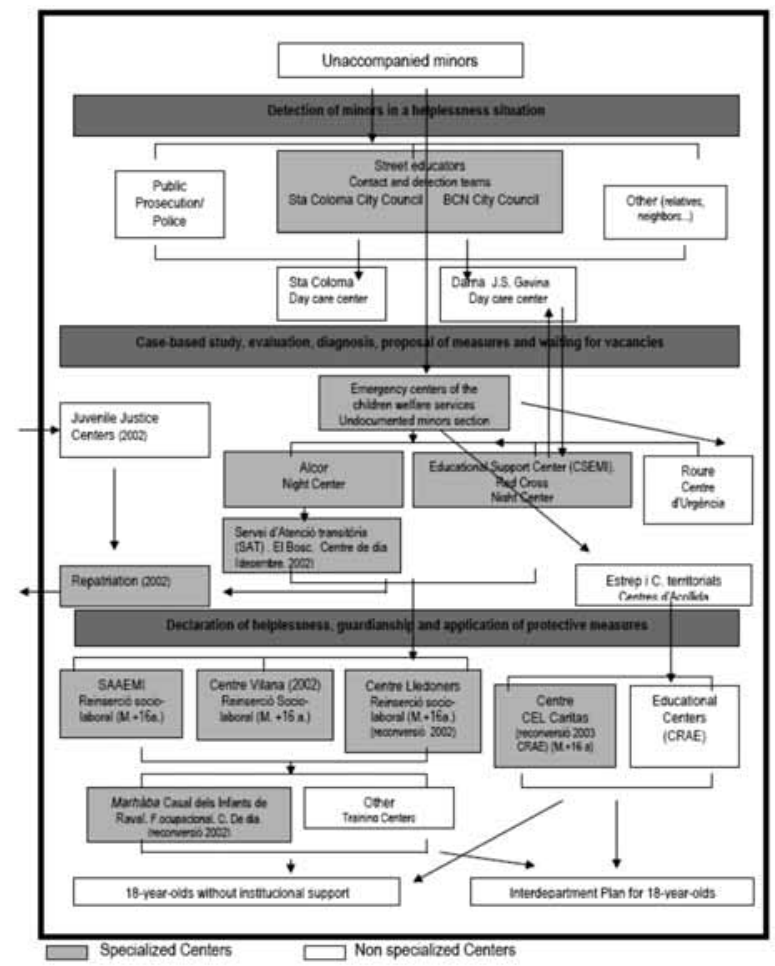

Figure 5. Catalan Children Protection Services in 2002. Source: Quiroga (2003) 
This sound transformation of administrative services, nevertheless, has not to be understood as the result of a global, coherent, top-down planning to enlarge and diversify the capacities of the existing system. Rather, changes obey to a patchwork-like process that reacts correspondingly by providing ad-hoc, transitive solutions that may last or not depending on future events (pressure to create new vacancies, budgetary allocations, agreements with non-profit organizations, etc.). From the administrative standpoint, the picture of the system in 2006 offered the view showed in figure 6 .

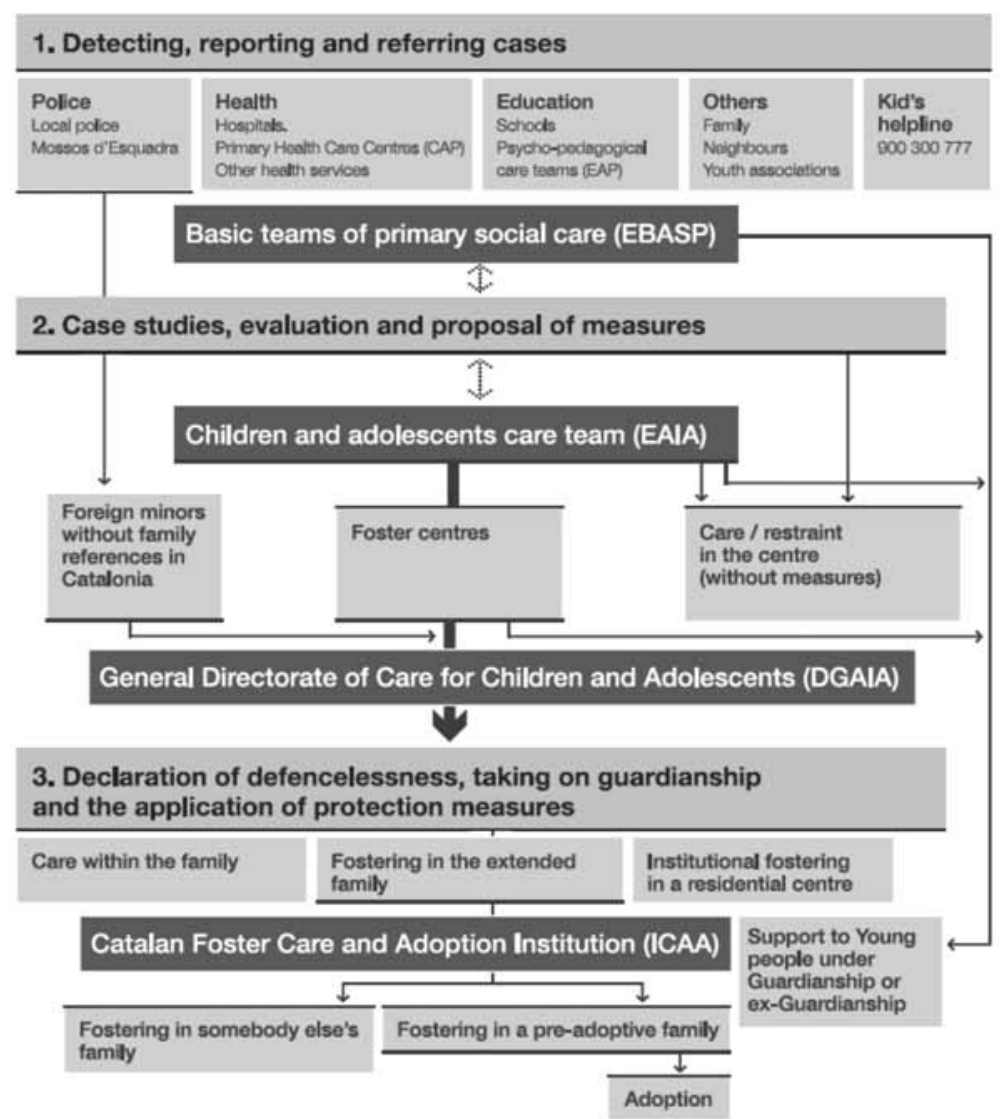

Figure 6. Catalan Children Protection Services in 2006.

Source: General Directorate of Care for Children and Adolescents (as of 2006)

The basic differences between the 2006 schema and the previous organizational arrangements lie in the creation of a specific network of both services and professionals to take care of foreign minors, including «initial foster centers» intended to «evaluate their migratory itinerary, their degree of 
defenselessness and the suitability of them remaining in our country» and «socio-labor integration resources» destined to those with a «possible migratory project» (General Directorate of Care for Children and Adolescents, 2006). While the nature of the administrative rearrangements received much criticism for its ongoing improvisation, it has also proved to be adaptive enough to deal with specific situations, and transform itself at every step of the process. At the present moment it is difficult to assess whether the system has reached the degree of maturity and stability enough to remain in place for a longer period, or, rather, it will soon be readapted depending on the contextual circumstances.

\section{Unaccompanied Children in the Political Debate}

\subsection{Research Questions}

Our main research question is: to what extent has the political debate run parallel to the substantial administrative reforms regarding MEINA over the last years. Given the thoroughness of the administrative reforms carried out so far, and given that Catalonia is a parliamentarian system, we might expect those reforms to have been triggered - or, at least, surrounded - by a certain amount and intensity of debate around immigrant children.

On the one hand, regarding the amount of parliamentarian activity, from 1998 to 2006, the Catalan Parliament action has adopted a variety of forms, including reports of the Catalan Ombudsman submitted to the Parliament, parliamentary motions and resolutions, rulemaking debates, and written pairs of parliamentary question-answers. However, given the substantial administrative changes on this issue carried out between 1998 and 2006, we might expect a particularly active parliamentary rulemaking activity on this specific issue. The truth, however, is that if we focus on the number of rulemaking activities in this area over the period covered, we have only been able to find the reform of the 37/1991 Act of December $30^{\text {th }}$ on protective measures of defenseless and adopted minors, and regulation of special attention to adolescents showing highly social risk behavior (8/2002 Act of May $\left.27^{\text {th }}\right)$.

Leaving aside the isolation of this legislative action, the very label of «adolescents with highly social risk behaviors» within the context of a reform in the area of dependent minors reveals a certain pattern of parliamentary discourse regarding «unaccompanied children» (MEINA) - the continuous oscillation of considering this group either dependent or deviant groups. Conversely, MEINA may be regarded as a dependent group because they are children: in this sense, they are powerless though positively seen. On the other hand, both the scarcity of legislative activity around the issue and the punishment-like type of a number 
of the (merely administrative) policies adopted by the administration may let us conclude that Catalan elected officials either (a) see MEINA as deviants instead of dependents, or (b) assume that the public sees MEINA as a deviant instead of a dependent group.

Because of this, the policies regarding MEINA are neither fully justiceoriented nor fully instrumental. The application of a justice-oriented policy would be only suitable for MEINA if the group were perceived positively (e.g., MEINA merely as powerless children). And thus, instrumental policies would only be suitable for MEINA if the more negative vision dominated (e.g., MEINA merely as petty offenders). In fact, the current policies for MEINA lack a clear orientation and their nature depends upon the political juncture.

On the other hand, our main interest lies in the intensity or content of this set of activities, for we might expect that MEINA would be part of the parliamentary agenda and thus appear in parliamentary discourse as one clear discursive dimension during the years covered. In particular, given that the administrative reforms discussed above have clear effects on the personal status and rights of minors, we expect to find this issue being a relevant dimension of the parliamentary debate. Our hypothesis is that provided that, as we have seen, immigrant children are given (1) a special administrative treatment in the reforms, and (2) special coverage in the media, they would also be given a distinctive and special attention in the parliamentary debates.

\subsection{Data}

Our data are four corpora of parliamentary texts from different activities carried out in the Catalan Parliament between 1999 and 2006 that (should) cover the case of MEINA in various ways.

\subsubsection{Annual Reports of the Ombudsman (Corpus A)}

Similarly to the Spanish Defensor del Pueblo, in Catalonia the Ombudsman [Síndic de Greuges] has been given the authority to inquire and scrutinize over the operation of the public administration. ${ }^{11}$ In October 1998, the Ombudsman

11. As it is well-known, the institution of the Ombudsman has a Scandinavian origin and spread over Europe in the second half of the twentieth century. As Magnette recalls, «in the political sense of the term, an Ombudsman is a public officer whose action is centred on public administration and who enjoys strong guarantees of independence. His power is characterized by the non-binding dimension of his decisions -contrary to national courts. The Ombudsman comes most frequently from the Parliament, which appoints and controls him, while theoretically preserving his autonomy» (Magnette, 2003). 
conducted an initial investigation with the aim of requesting information and scrutinizing the role of the different public administrations in dealing with the arrival of unaccompanied children. This ended by making recommendations on how to take adequate steps to preserve the principle of the «best interest of the child» in the administrative procedures. A summary of this inquiry is included in the Ombudsman 1999 annual report. Similar inquires were included in the reports from 1999 to 2006. This corpus includes the transcripts of the parliamentary sessions that include both the presentation of the reports by the Ombudsman, and the public statement made afterwards by the leader of each parliamentary group. These partisan statements are meant to debate the issues outlined by the Ombudsman, although they usually take the form of each group thanking the Ombudsman for the task performed by him, and his team and making some unidirectional comments about the annual report without further crossing interventions.

\subsubsection{Parliamentary Motions and Resolutions (Corpus B)}

Corpus B consists of a set of 10 parliamentary texts including motions and resolutions adopted by the majority of members of the Catalan Parliament on the issue of unaccompanied children during the years 2000-2002. These are typically short statements (no more than one page long) asking the government to adopt some measures regarding this issue. Consider these two examples below:

The Parliament of Catalonia urges the government to present, within the lapse of twelve months, a new model of attention to defenseless minors in a situation of high social risk.

[El Parlament de Catalunya insta el Govern a presentar, en el termini de dotze mesos, a la Comissió de Justícia, Dret i Seguretat Ciutadana un nou model d'atenció als menors desemparats $i$ en situació d'alt risc social] Extracted from Motion 15.03.2000

The Parliament of Catalonia urges the government to improve the protection and immediate attention of the minors living in the street with no family referents through the creation of new resources, as it is its authority.

[El Parlament de Catalunya insta el Govern a millorar la protecció i l'atenció immediata dels menors que viuen al carrer que no tenen referents familiars al nostre país i que presenten conductes dissocials, mitjançant la creació de nous recursos, en compliment de la competència que té atribuïda] Extracted from Resolution 07.03.2002 


\subsubsection{Rulemaking Debates (Corpus C)}

Rulemaking debates consist of the two debates (plenary session of the Parliament and discussion carried out in a committee) leading to the adoption of the reform of the $37 / 1991$ Act of December $30^{\text {th }}$ on protective measures of defenseless and adopted minors and regulation of special attention to adolescents with behaviors in a situation of high social risk (8/2002 Act of May $\left.27^{\text {th }}\right)$. The full session of the Parliament unanimously approved the proposed reform, which had been previously discussed and negotiated by all parliamentary groups in a committee.

\subsubsection{Written Pairs of Questions-Answers (Corpus D)}

This corpus includes 21 pairs of written questions-answers, submitted by members of the Parliament to the government during the period 1999-2006, that tackle upon the issue of our interest. Here is an example of parliamentary question to the executive:

Núria de Gispert i Català, representative of the parliamentary group Convergència $i$ Unió, in accordance with article 132 of the Regulation of this Parliament, formulates the following written question to the Executive:

- Which resources of all sorts are destined to foreign minors? Which are the current agreements with non profit social organizations to take care of these minors? Which is the budget destined to these minors? ${ }^{12}$

Parliament, January $17^{\text {th }} 2005$

[Núria de Gispert i Català, diputada del Grup de Convergència i Unió, d'acord amb el que s'estableix a l'article 132 del Reglament de la Cambra formula la següent pregunta per escrit al Consell Executiu,

- Quins recursos de tot tipus es destinen als menors estrangers? Quins convenis són vigents amb entitats d'iniciativa social per atendre aquests menors? Quin és el pressupost que es destina a aquests menors?

Palau del Parlament, 17 de gener de 2005].

12. And here is the answer: «In accordance with article 132 of the Regulation of this Parliament, we communicate the following considerations to you: the Welfare and Family Department, through the General Directorate of Infancy and Adolescence (DGAIA) takes care of foreign minors through specific programs and services, and also through the general protection network (residential and educational centers, fostering centers, and programs from the plan for the over 18 years-old). Specific resources for foreign minors in agreement with non profit social organizations include: [...] [see list of centers below]. In addition, it is worth mentioning the street educators in Barcelona and Santa Coloma de Gramenet, in agreement with their respective municipalities. Barcelona, March 7th 2005, Anna Simó i Castelló, Counselor of the Welfare and Family Department».

[D'acord amb el que disposa l'article 132 del Reglament del Parlament de Catalunya, us comuniquem les següents consideracions: El Departament de Benestar i Família, a través de la Direcció General 


\subsection{Methodology: Computer-Assisted Text Analysis}

The content analysis of political texts bears a long tradition in political science, which in modern times may be traced back to Lasswell et al.'s attempts to carry out a systematic and quantitative study of the language of politics (Lasswell et al., 1949). This and other recent empirical approaches to the analysis of political texts have successfully used classic content analysis techniques to explore research questions regarding framing political content in the media (e.g., Semetko \& Valkenburg, 2000), the assessment of policy dimensions in party manifestos (e.g., Klingemann et al., 2006), the assessment of lobby influence in policy processes (Klüver, 2009), ${ }^{13}$ and also the analysis of parliamentary debate on particular issues (Bara et al. 2007). Traitional content analytic techniques have obvious advantages over more interpretive approaches. First, they enable the analysis of relatively large amounts of raw text (Bailey \& Schonhardt-Bailey, 2008). Second, they attempt to avoid serious measurement problems, such as invalidity caused by the presence of nonrandom error (Carmines \& Zeller, 1979), and, in particular, by the systematic effect of the researcher's subjective biases (Neuendorf, 2002) on the analysis. And third, they rely on well-established methodologies that help reporting and foster replicating the results as part of the basic scientific endeavor (Krippendorff, 2004; Semetko \& Valkenburg, 2000).

However, as a general principle traditional content analysis is based on the codification of (units) of texts, which poses some challenges that automated, computer-assisted text analysis helps overcoming. First, although traditional content analysis efforts have been able to analyze relatively large amounts of

d'Atenció a la Infància i l'Adolescència (DGAIA) atén els menors estrangers mitjançant programes i serveis específics i a través, també, de la xarxa protectora general (centres residencials d'acció educativa, centres d'acolliment i programes del Pla per a majors de 18 anys). Els recursos específicament destinats a menors estrangers i conveniats amb entitats d'iniciativa social són els següents:

Centres de primera acollida:

1. Alcor (centre de primera acollida nocturn): conveni amb l'entitat APIP.

2. CESEMI (servei de primera acollida nocturn): conveni amb l'entitat Creu Roja i l'Ajuntament de Barcelona.

3. El Bosc (Servei d'atenció transitòria diürn): servei de gestió delegada a l'entitat ACISFJ.

Recursos d'inserció sociolaboral:

1. Centre Els Lledoners: conveni amb la Fundació Mercè Fontanilles.

2. Centre Vilana: centre de gestió delegada a la Fundació Mercè Fontanilles.

3. Centre AlQàntara: conveni amb Càritas Diocesana.

4. SAAEMI (programa d'autonomia): conveni i gestió amb la Fundació Mercè Fontanilles.

Així mateix, també cal esmentar el recurs dels educadors de carrer (a Barcelona ciutat i Santa Coloma de Gramenet en conveni amb els ajuntaments respectius)

Barcelona, 7 de març de 2005, Anna Simó i Castelló, Consellera de Benestar i Família.

13. Although Klüver combines and compares hand-coding results with automated quantitative text analysis techniques. 
text, their need for codification makes this activity seriously time- and resourceconsuming, even when coding is semi-automated or requires the construction and cross-validation of some kind of dictionary (Krippendorff, 2004). Second, given that automated computer text-analysis does not use codification, it has no limits in the amount of text to be analyzed, and thus it does not require putting much attention to sampling (Bailey \& Schonhardt-Bailey, 2008). And third, the use of human coders for large content analytic projects (e.g., Klingemann et al., 2006) raises measurement issues regarding the reliability of the resulting data and forces costly inter-coder reliability tests, which in big projects, due to the costs of coding, cannot avoid other measurement problems (Budge \& Pennings, $2007 a, 2007$ b; Benoit \& Laver, 2007; Benoit et al., 2009) that may be surmounted by computer text analysis.

As a result, computer-assisted, automated text analysis of political texts has captured an increasing amount of attention by political scientists and other social scientists in the last decades. These scientists have followed different techniques such as traditional multivariate statistics applied to text (Schonhardt-Bailey, 2005), frequency-based techniques for document classifying (Laver et al., 2003; Lowe, 2008), and word distribution-based document scaling (Slapin \& Prosch, 2008).

We analyze our parliamentary textual data with the tool ALCESTE, which has been used in similar scenarios by Schonhardt-Bailey (2005), and Bailey \& Schonhardt-Bailey (2008). ${ }^{14}$ ALCESTE is a textual data analysis software tool created by Max Reinert $(1986,1987)$. It was designed to measure, classify, and represent the main thematic classes appearing in a text, a corpus or a set of corpora through the application of (1) a multivariate technique, such as correspondence analysis on very sparse chunk-word matrices, and (2) a hierarchical classification of text chunks into clusters that somehow represent the main thematic classes to be found in the textual data. ${ }^{15}$ These classes (or lexical worlds) subscribe to different types of discourse, each of which shows a specific set of representative vocabulary. Both keywords and chunks are, moreover, ranked in terms of their statistical significance (summarized through the chi-squared statistic) and both can be traced back to the original text, so that it is possible to evaluate their context.

14. ALCESTE stands for Analyse des Lexèmes Co-occurents dans les Énoncés Simples d'un Text [Analysis of the co-occurrent lexemes within the simple statements of a text] and its algorithm was created by Max Reinert at the CNRS - partly based on Bénzecri's contributions on textual statistics. See Murtagh (2005) for an assessment (in English) of Bénzecri's contributions, which includes a foreword by Bénzecri himself.

15. More precisely, what the program extracts by default are not really words but word reductions from a dictionary. This reduction in our case was not in order - as we shall explain later - and we fed the program with already reduced texts. Thus, a «most significant word» is not a single type in the text, and an ECU is not necessarily a natural sentence. 
ALCESTE is automatic and thus does not require any hand-made categorization, coding scheme, or thematic dictionary whatsoever. Instead, it extracts the thematic classes of the text from scratch and regardless of the natural structure of the corpus.

The goal of ALCESTE is to quantify the text so as to extract its most significant structures. This activity is based on a general principle about discourse: it is conceived of as not depending on its representation, but according to the activity that takes place in it (Reinert, 2003). This activity is repetition, the main factor for conceiving the stabilisation of a discursive activity.

ALCESTE thus analyzes repetition statistically in many ways (but mainly through the analysis of large sparse matrices), but finally it allows for the study of something like the «topography of a discourse» by creating, confronting, and representing different lexical worlds from it. In other words, the most significant structures of a text are deeply linked to the distribution of terms in it. Thus we can model the trace of the meaning of a text as the trace of a discourse activity (production and repetition of signs) (Bastin, 2002).

The methods used by ALCESTE are basically correspondence analysis and hierarchical decreasing classification (HDC), and its operation is based on the successive split of the text in smaller chunks; then one observes the distribution of most significant words within every chunk - i.e., it extracts the most representative words from the text.

A most significant word is not a lexeme, and a chunk does not need to be a complete (or full-meaning) statement or sentence. As a program of distributional statistical analysis, its working mechanisms are independent from meaning. This is to say that there is no need to have precise units for representing a concrete object (Reinert, 2003). The quantitative aspect of the repetition of most significant words is not the relevant point. What is really important in our analysis with ALCESTE is the presence or absence of words. The co-occurrence of most significant words translates the «associative background» (or topic background) that operates within the text: closeness (temporal in the statement or spatial in the text) of most significant words shows the work of the same topical origin (Bastin, 2002).

ALCESTE «breaks» the text into different chunks or context units, since it recognizes the forms in the context units. There are two kinds of context to be distinguished:

- Initial Context Units (ICU). They are the different «natural» parts of the corpus (i.e., they may be conceived of as sampling units (Bailey \& Schonhardt-Bailey, 2008)), and the biggest context units. They can be different texts (e.g., journal papers) or different parts of the same text (e.g., book chapters, different answers to a questionnaire, etc.). The variables 
attributed to these text segments enable crossing them quickly. This first fragmentation is not required, though: one can trait a corpus without tagging any variable before the analysis.

- Elemental Context Units (ECU). The second fragmentation of the corpus is made by ALCESTE defining the «sentences» according to which it will perform the analysis. This fragmentation is eventually based upon punctuation and tries to achieve a balanced number of words per ECU.

In order to achieve its results, the program classifies the chunks of the corpus (the ECU) according to the distribution of the vocabulary that occurs within them. The program then finds the vocabulary in the different context units and relates them. In other words, the program connects those contexts that have common words, finds the strongest vocabulary oppositions and extracts some categories of representative statements. The relatedness of words to chunks is computed through the chi-squared distance - i.e., correspondence analysis of a binary chunk-term matrix.

Another important type of unit for the program concerns the lexical unit. The program identifies the occurrences of every form through a dictionary by default. However, given that ALCESTE has no Catalan dictionary among its features, we have previously lemmatized the texts using MACO (Carmona et al., 1998) and FreeLing (Padró et al., 2010) ${ }^{16}$ so as to minimize unnecessary noise in the analysis. ${ }^{17}$

From the partition of the text in context units, the corpus is modelled through a huge contingency table (a very sparse data matrix) that comprises the chunks in rows and the terms in columns. Each cell represents the presence/absence of a term in a particular chunk. Then the program cross-checks the context units with the presence/absence of forms through distance matrices - based on chisquared distance (Murtagh, 2005) - of row margins and column margins. ${ }^{18}$ After that, it creates clusters of ECU that minimize intra-class and maximize extra-class distances (Greenacre, 1993). ${ }^{19}$ In an iterative way, the program ends

16. <http://nlp.lsi.upc.edu/freeling $>$.

17. Vallbé et al. (2007) show that in different languages such as Catalan and Slovenian, noise reduction improves significantly the quality of results when natural language processing is performed with lemmatized text compared to raw text. One of the tests is actually performed using ALCESTE.

18. A column margin or profile expresses the «profile» of a particular word, i.e. the chunks in which that word occurs. The analogy is applied to chunks when computing row profiles.

19. As mentioned above, distance in correspondence analysis is computed as chi-squared distance and it is represented in correspondence maps through the low-dimensional representation of two distance matrices (for rows and columns). The larger the distance between two classes (i.e., the less common their terms), the further they appear in the correspondence map. The superimposition of matrices and the use of the chi-squared distance «ensure that proximity between rows and columns in the merged map is as good an approximation as possible of the correlation between rows and columns» (Baayen, 2008: 139). 
up with a stable number of classes containing sets of significantly associated ECU.

These classes present the same type of «symbolic repetition». The program thereby shows the main «lexical worlds» of the corpus (Reinert, 2000, 2003) - i.e., the sets of words that are most particularly associated to a class. Or, in other words, the identification of the main dimensions of a discursive action allows keeping track of those themes that have entered the «discursive agenda» and those that have not. The graphic representation of the classes and the distribution of their most representative terms in correspondence maps allows for the interpretation of the closeness, overlapping, or opposition of issues.

\section{Results of the Analysis of Parliamentary Textual Corpora}

In Table 3 we show some basic statistics of the texts that have been analyzed, once the texts have been lemmatized. The first thing we may notice is that the Corpus A is far larger than the other ones, because it comprises full-length transcripts of the debates regarding the Catalan Ombudsman's annual report between 1998 and 2006. Corpora C and D are quite similar in all statistics, while Corpus B is the smallest of our corpora. The first row of the table shows the number of different words in each corpus (i.e., types), while the second row indicates the total frequency of occurrences in each corpus (i.e., tokens). The other rows show, respectively, the maximum and the minimum frequency of a word, the mean frequency, the median, and the standard deviation of the frequencies. These statistics are indicators of the heavily tailed nature of word-frequency distributions in natural language corpora, in which very few words have large frequencies, but most terms occur just a few times.

Table 3. Basic statistics of the texts analyzed by ALCESTE

\begin{tabular}{|lllll|}
\hline & $\begin{array}{l}\text { Corpus A } \\
\text { (ombudsman) }\end{array}$ & $\begin{array}{l}\text { Corpus B } \\
\text { (motions and } \\
\text { resolutions) }\end{array}$ & $\begin{array}{l}\text { Corpus C } \\
\text { (rulemaking } \\
\text { debates) }\end{array}$ & $\begin{array}{l}\text { Corpus D } \\
\text { (question- } \\
\text { answer) }\end{array}$ \\
\hline Num. of words & 10529 & 608 & 1313 & 1467 \\
Occurrences & 344260 & 1984 & 4977 & 6591 \\
Max. frequency & 26544 & 69 & 343 & 324 \\
Min. frequency & 1 & 1 & 1 & 1 \\
Mean & 32.7 & 3.26 & 3.79 & 4.49 \\
Median & 3 & 2 & 1 & 1 \\
Std. deviation & 324.25 & 5.45 & 12.75 & 14.19 \\
\hline
\end{tabular}


In order to have a clean grasp of the discursive dimensions in each corpus, we have analyzed them separately. We have summarized the results in tables containing the number of classes identified by the program, the number of elementary context units (ECU) or utterances automatically constructed by the program based on word length and punctuation, the most representative words for each class and their chi-squared score, and samples of representative ECU of each class. We also include a graph for each sub-corpus representing correspondence analysis of its respective classes.

Table 4 and Figure 7 show results of Corpus A (Annual Reports of the Ombudsman). The first two factors of the correspondence analysis, which are represented in figure 4 through the horizontal and vertical axes, account for 67 percent of the variance. This first representation suggests that discourse cleavages are minimal in this corpus, given the systematic overlapping of terms corresponding to classes $1,2,3$, and 4 . The only dissociated position corresponds to class 5, which occupies an extreme position on the x-axis (factor 1). However, the most representative vocabulary of this class consists of terms referring to actors or procedures of the Catalan Parliament, such as speaker, Member of Parliament, speech turn, and ombudsman.

Table 4. Statistical synthesis of annual reports of the Ombudsman (Corpus A)

\begin{tabular}{|c|c|c|c|c|}
\hline Class & ECU & Representative words & Chi square & Representative ECU (*) \\
\hline 1 (red) & 330 & $\begin{array}{l}\text { jo [I] } \\
\text { creure [believe] } \\
\text { tema [issue] } \\
\text { sindicatura [ombudsman] } \\
\text { pregunta [question] }\end{array}$ & $\begin{array}{l}67.51 \\
58.25 \\
43.35 \\
31.81 \\
24.99\end{array}$ & $\begin{array}{l}\text { jo creure que ser molt important en } \\
\text { aquest sentit per el mateix imatge i } \\
\text { legitimitat de el sindicatura } \\
\text { questio que estic segur que poder } \\
\text { resoldre i millorar pero es problema } \\
\text { que s'arrossega de fa molts anys }\end{array}$ \\
\hline 2 (green) & 334 & $\begin{array}{l}\text { normativa [legal norms] } \\
\text { seguretat [security] } \\
\text { alumne [student] } \\
\text { estranger [foreigner] } \\
\text { immigrant [immigrant] }\end{array}$ & $\begin{array}{l}36.5 \\
27.38 \\
27.19 \\
27.07 \\
23.67\end{array}$ & $\begin{array}{l}\text { caldre evitar el problema derivat de el } \\
\text { alt concentracio de nen immigrant en } \\
\text { determinat escola } \\
\text { comprovar el compliment de norma- } \\
\text { tiva regulador de seguretat privada } \\
\text { efectuar un estudi sobre dret de edu- } \\
\text { cacio de el fill immigrant }\end{array}$ \\
\hline 3 (blue) & 166 & $\begin{array}{l}\text { administracio [administration] } \\
\text { administratiu [administrative] } \\
\text { informacio [information] } \\
\text { procediment [procedure] } \\
\text { irregularitat [irregularity] }\end{array}$ & $\begin{array}{l}156.89 \\
77.11 \\
54.55 \\
54.48 \\
44.65\end{array}$ & $\begin{array}{l}\text { Hi ha administracio que creure enca- } \\
\text { ra que amb resposta oral n'hi ha prou } \\
\text { ho creure que hi haver un autentic } \\
\text { desproteccio de ciutadans }\end{array}$ \\
\hline
\end{tabular}

(*) Editorial Note: Even though the Catalan language presented in the research data of this article includes a considerable amount of errors and misspellings, derived from the computer programmes used to collect and classify such data, it has not been modified or amended for the Editorial Team. 


\begin{tabular}{|c|c|c|c|c|}
\hline 4 (yellow) & 283 & $\begin{array}{l}\text { familia [family] } \\
\text { economic [economic] } \\
\text { residencial [residential] } \\
\text { dona [woman] } \\
\text { acolliment [foster care] }\end{array}$ & $\begin{array}{l}99.33 \\
63.36 \\
58.05 \\
53.67 \\
51.13\end{array}$ & $\begin{array}{l}\text { familia amb renda mitja, actualment } \\
\text { continuar constatar que el regim adre- } \\
\text { çat a unitat familiar amb escassetat de } \\
\text { recursos economics } \\
\text { vincular el fet de donar recurs a fami- } \\
\text { lia per stencio a gent gran o persona } \\
\text { en situacio de dependencia }\end{array}$ \\
\hline 5 (purple) & 113 & $\begin{array}{l}\text { president [speaker] } \\
\text { diputad+ [member of } \\
\text { parliament] } \\
\text { paraula [speech turn] } \\
\text { mesa [board] } \\
\text { sindic_greuge [ombudsman] }\end{array}$ & $\begin{array}{l}440.99 \\
245.71 \\
\\
162.32 \\
120.43 \\
100.4\end{array}$ & $\begin{array}{l}\text { gracies senyor president en nom de } \\
\text { el grup parlamentari ciutadans pel } \\
\text { canvi } \\
\text { simplement donar les gracies en nom } \\
\text { del grup popular } \\
\text { gracies senyor sindic, gràcies senyor } \\
\text { president }\end{array}$ \\
\hline
\end{tabular}

A similar landscape can be found in Corpus B (parliamentary motions and resolutions) represented by table 5 and figure 8 , where class 4 , corresponding to procedural expressions, is moderately detached. In this case, the first two factors of the correspondence analysis performed by ALCESTE account for the cumulative 75 percent of the variance. What is worth mentioning here is certain distinction of classes 1 and 2 along the y-axis, although there is some overlapping between them. While class 1 represents the «dependent group» view of MEINA (with terms such as action, childhood, and foster care), class 2 includes words recalling the «deviant group» vision of them (terms such as high risk, social risk).

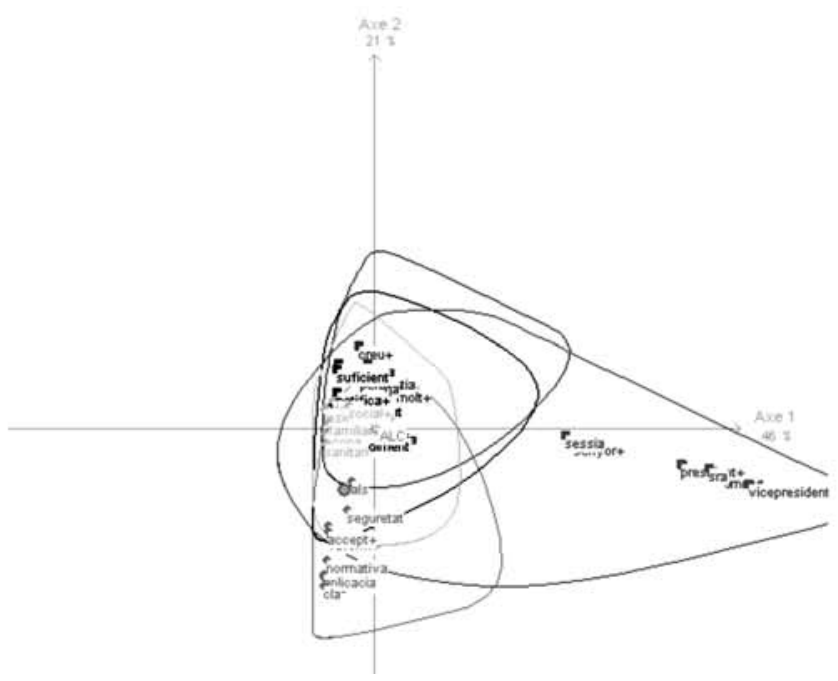

Figure 7. Correspondence analysis of annual reports of the Ombudsman (corpus A) 
This may be understood as the mapping of the oscillation suggested in Section 5 as featuring the first parliamentary discursive pattern. Interestingly, however, class 3 , which is best represented by the term funding, covers the same correspondence space of both class 1 and 2, suggesting that these different visions on MEINA represented by classes 1 and 2 are overlapped by the discussion on the resources to be spent.

Table 5. Statistical synthesis of parliamentary motions and resolutions (Corpus B)

\begin{tabular}{|c|c|c|c|c|}
\hline Class & ECU & Representative words & Chi square & Representative ECU \\
\hline 1 (red) & 26 & $\begin{array}{l}\text { increment [increase] } \\
\text { infancia [childhood] } \\
\text { actuació [action] } \\
\text { educatiu [educational] } \\
\text { acolliment [foster care] }\end{array}$ & $\begin{array}{l}15.29 \\
13.24 \\
11.11 \\
11.11 \\
9.18\end{array}$ & $\begin{array}{l}\text { traslladar el menor i el Jove als centre } \\
\text { d'atencio a infancia mes adequat per } \\
\text { a poder hi exercir el funcio educatiu i } \\
\text { protectora } \\
\text { fer progressivament el inv necessaries } \\
\text { per tal que el centre de acolliment } \\
\text { obtenir un distribució adequat de el } \\
\text { espai }\end{array}$ \\
\hline 2 (green) & 18 & $\begin{array}{l}\text { marc [framework] } \\
\text { social [social] } \\
\text { model [model] } \\
\text { alt [high] } \\
\text { risc [risk] }\end{array}$ & $\begin{array}{l}25.17 \\
24.13 \\
18.96 \\
18.8 \\
17.14\end{array}$ & $\begin{array}{l}\text { multiplicitat de tipologies de menor } \\
\text { en situacio de risc social i el el marc } \\
\text { de el futur model d atencio a el menor } \\
\text { impulsar, en el marc de el taula de } \\
\text { seguiment de el acord de col-laboracio } \\
\text { i compromis per millorar el resposta } \\
\text { institucional a el problema social de } \\
\text { immigracio de menor i jove indocu- } \\
\text { mentat en situacio de alt risc social }\end{array}$ \\
\hline 3 (blue) & 10 & $\begin{array}{l}\text { finançament [funding] } \\
\text { revisar [check] } \\
\text { servei [service] } \\
\text { modul [module] } \\
\text { desemparats [helpless] }\end{array}$ & $\begin{array}{l}70 \\
54.19 \\
54.19 \\
54.19 \\
26.25\end{array}$ & $\begin{array}{l}\text { revisar el criteri i el modul actualment } \\
\text { vigent com a tot el servei prestar en } \\
\text { el ambit de el atencio i el proteccio de } \\
\text { el menor desemparats i en situacio } \\
\text { de alt risc social } \\
\text { el parlament de catalunya, ates que el } \\
\text { suficiencia de el sistema de recurs } \\
\text { nomes es poden assolir en un finan- } \\
\text { çament adequat, insta a el govern a }\end{array}$ \\
\hline 4 (yellow) & 16 & $\begin{array}{l}\text { interpel·lació [question] } \\
\text { consell executiu } \\
\text { [executive board] } \\
\text { moció [motion] } \\
\text { ple de el parlament } \\
\text { [plenary of the } \\
\text { parliament] } \\
\text { aprovació [approval] }\end{array}$ & $\begin{array}{l}59.06 \\
59.06 \\
45.25 \\
39.38 \\
\\
22.15\end{array}$ & $\begin{array}{l}\text { mocio subseguent a el interpel-lacio } \\
\text { a el consell executiu sobre el menor } \\
\text { que viure a el carrer, aprovacio } \\
\text { mocio subseguent a el interpel·lacio } \\
\text { a el consell executiu sobre el centre } \\
\text { de acolliment per a infant i } \\
\text { adolescent desamparats, aprovacio }\end{array}$ \\
\hline
\end{tabular}




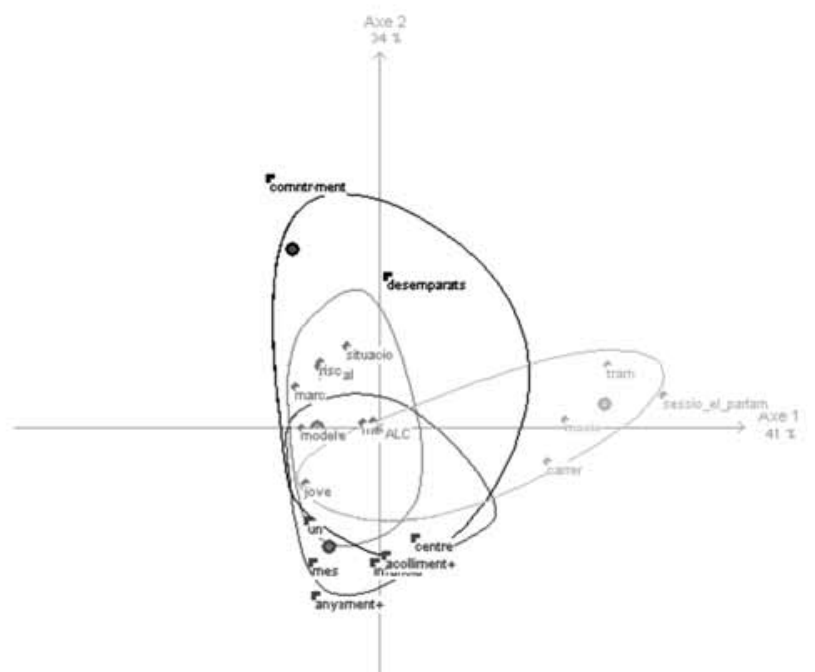

Figure 8. Correspondence analysis of parliamentary motions and resolutions (Corpus B)

Figures 9A and 9B, and tables 6 and 7 summarize results for Corpus $\mathrm{C}$ (parliamentary debates). We have subdivided this corpus into two subsets: plenary sessions of the Parliament and committee sessions (involving only those members of parliament enrolled in the specific working group). The reason for this split of the texts is the expectation that at least the debates held in private committee sessions might show clearly opposed policy positions around MEINA. On the one hand, as may be seen in table 7, all the classes created by ALCESTE regarding the texts corresponding to plenary sessions have an equal weight - i.e., they are formed by a similar number of ECU. Once we represent them according to the first two factors of the correspondence analysis (figure 6A), the classes appear highly overlapped forming a big circle in the middle of the plot, which accounts for 52 percent of the variance. Classes 1 and 3 may represent, again, the two distinctive visions of MEINA, although overlapping indicates that there is not clear opposition among the classes. In contrast, classes 2, 4, and 5 contain procedural and parliamentarian vocabulary.

On the other hand, figure 6B and table 8 show a different pattern. In this case, one class clearly outweighs the others and occupies a small, centred circle in figure 6B (class 4, yellow). The two factors in this picture represent 72 percent of the variation in the correspondence analysis. Some conclusions may be drawn from both representations. First, as expected, it appears that, while many issues are discussed in the plenary sessions, no sharp oppositions are presented during these discussions. Thus, there is not a single issue on which attention is centred. Second, the parliamentary commissions hardly discuss a variety of issues, but 
limit the discourse to minor legal and legislative matters, as shown in table 8. In this case, class 4 , representing 5 times more ECU than class 2, and 9 times more than classes 1 and 3 , and occupying the central position of the correspondence analysis plot (which indicates lack of opposition and might be viewed as consensual), represents this kind of discursive behavior. Moreover, figure 6B shows that any other kind of (more political) discourse (as the one represented by class 3 ) is marginal and occasional, since it represents only a tiny portion of what is represented by this class.

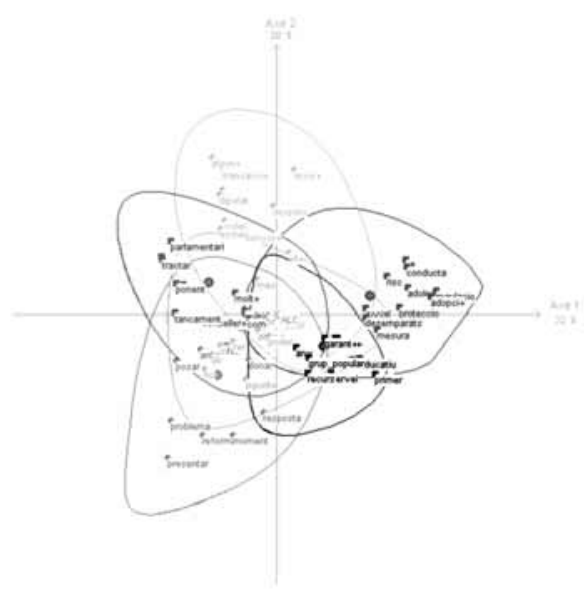

Figure 9A. Plenary sessions

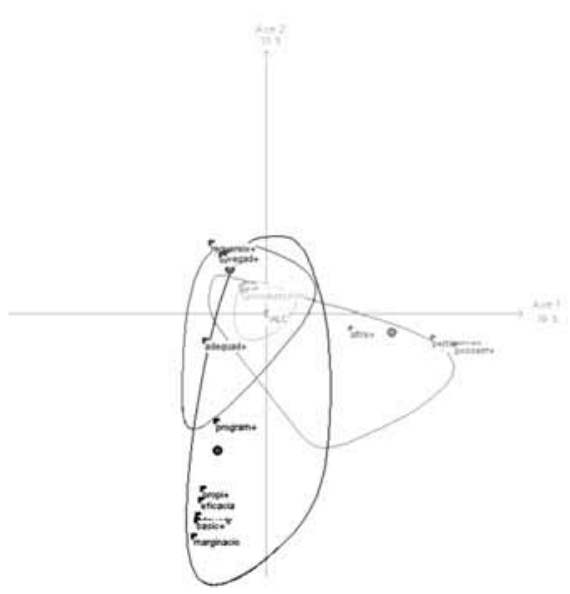

Figure 9B. Committee sessions

Figure 9. Correspondence analysis of parliamentary debates (Corpus C, commission session)

Table 6. Statistical synthesis of parliamentary debates (Corpus C, plenary session)

\begin{tabular}{|c|c|c|c|c|}
\hline Class & ECU & Representative words & Chi square & Representative ECU \\
\hline 1 (red) & 25 & $\begin{array}{l}\text { proteccio [protection] } \\
\text { adolescent [adolescent] } \\
\text { alt [high] } \\
\text { conducta [behavior] } \\
\text { risc [risk] } \\
\text { rebutjar [to reject] }\end{array}$ & $\begin{array}{l}51.02 \\
39.36 \\
37.68 \\
32.7 \\
24.03 \\
23.45\end{array}$ & $\begin{array}{l}\text { mesura de proteccio de el menor } \\
\text { desemparats i regulacio i adopcio de } \\
\text { la atencio especial de adolescent en } \\
\text { situacio de alt risc social } \\
\text { una atencio especial mereixer el situa- } \\
\text { cio de el menor i jove sense llar, prin- } \\
\text { cipalment, encara que no } \\
\text { exclusivament, estranger, sovint indo- } \\
\text { cumentat, sense referent familiar } \\
\text { i amb contucta de alt risc social }\end{array}$ \\
\hline
\end{tabular}




\begin{tabular}{|c|c|c|c|c|}
\hline 2 (green) & 20 & $\begin{array}{l}\text { govern [government] } \\
\text { presentar [to present] } \\
\text { reforma [reform] } \\
\text { problema [problem] } \\
\text { taula [table] }\end{array}$ & $\begin{array}{l}50.1 \\
43.51 \\
36.53 \\
31.12 \\
24.3\end{array}$ & $\begin{array}{l}\text { i tambe poder palpar el manca de } \\
\text { coordinacio entre diferents adminins- } \\
\text { tracions per posar solucions sobre la } \\
\text { taula; mentre aixo passar evidentment } \\
\text { el problema anava agreujar i per aixo } \\
\text { el resposta no poder ser unicament el } \\
\text { reforma legislativa } \\
\text { es un problema que al govern de la } \\
\text { generalitat no el venir de bell nou, es } \\
\text { un problema que es va debatre, que } \\
\text { es va posar damunt de el taula en el } \\
\text { substanciació de diverses } \\
\text { interpel-lacions i mocions presentades }\end{array}$ \\
\hline 3 (blue) & 39 & $\begin{array}{l}\text { educatiu [educational] } \\
\text { servei [service] } \\
\text { menor [minor] } \\
\text { acció [action] } \\
\text { adolescencia [adolescence] }\end{array}$ & $\begin{array}{l}19.66 \\
16.91 \\
14.1 \\
13.17 \\
13.17\end{array}$ & $\begin{array}{l}\text { es innegable que dins d'aquest } \\
\text { col-lectiu s ha produït } 1 \text { arribada, } \\
\text { nombrosa, de menors immigrants als } \\
\text { quals caldre donar també resposta } \\
\text { adequada [...] } \\
\text { haver de veure, en el darrer any, } \\
\text { reduir el nombre de educadores i } \\
\text { educadors socials; haver patir una } \\
\text { manca de polítiques integrals de ado- } \\
\text { lescencia; haver de reconeixer, tot } \\
\text { plegat, la manca de recurs per desen- } \\
\text { volupar mesura educatiu }\end{array}$ \\
\hline 4 (yellow) & 20 & $\begin{array}{l}\text { esmena [ammendment] } \\
\text { transacció [transaction] } \\
\text { lliurar [deliver] } \\
\text { revisar [to check] } \\
\text { considerar [to consider] } \\
\text { diputat [MP] }\end{array}$ & $\begin{array}{l}42.11 \\
36.53 \\
24.3 \\
19.29 \\
18.09 \\
17.96\end{array}$ & $\begin{array}{l}\text { naturalment, aquesta mesura, també } \\
\text { com a mesura de cautela, s'ha de } \\
\text { revisar setmanalment } \\
\text { algun requerir tambe modificacio d } \\
\text { altres llei, llei de benestar social }\end{array}$ \\
\hline 5 (purple) & 16 & $\begin{array}{l}\text { tema [issue] } \\
\text { parlamentari [parliamentary] } \\
\text { tractar [to deal with] } \\
\text { parlament [parliament] } \\
\text { grup [group] } \\
\text { polítiques [policies] }\end{array}$ & $\begin{array}{l}39.52 \\
35.88 \\
31.5 \\
23.38 \\
18.15 \\
12.22\end{array}$ & $\begin{array}{l}\text { parlar de menor i no parlar de delin- } \\
\text { qüents, i aquest, senyor conseller, ai } \\
\text { las! es el gran tema: son menors o son } \\
\text { delinqüents? i com anar a protegir } \\
\text { aquest menor, menor desamparats, i } \\
\text { jo, amb tot el treball parlamentari, } \\
\text { haver ser sempre partidari de politi- } \\
\text { ques i no de tancament, haver ser } \\
\text { partidari de tractar aquest tema amb } \\
\text { serenitat i no amb urgencia }\end{array}$ \\
\hline
\end{tabular}




\begin{tabular}{|l|l|l|l|l|}
\hline $\begin{array}{l}\text { 6 (electric } \\
\text { blue) }\end{array}$ & 18 & $\begin{array}{l}\text { abans [before] } \\
\text { fer [to do] } \\
\text { mes [month] } \\
\text { si [if] }\end{array}$ & $\begin{array}{l}20.51 \\
20.05\end{array}$ & $\begin{array}{l}\text { mes cura encara a l hora de tenir en } \\
\text { compte aixo, el pressio social el fer el } \\
\text { jurista, el professional, el institucio, } \\
\text { perque voler uns instrument util i } \\
\text { eficaç per poder portar a terme el seu } \\
\text { feina } \\
\text { arribar en el maxim acord possible, jo } \\
\text { si m ho permetre (...) jo tenir impres- } \\
\text { sio d aquell corredor de bicicletes que } \\
\text { fer una carrera i te una punxada i una } \\
\text { altra }\end{array}$ \\
\hline & & & \\
& & & \\
\hline
\end{tabular}

Table 7. Statistic synthesis of parliamentary debates (Corpus C, committee session)

\begin{tabular}{|c|c|c|c|c|}
\hline Class & ECU & Representative words & Chi square & Representative ECU \\
\hline 1 (red) & 32 & $\begin{array}{l}\text { vegada [time] } \\
\text { mes [month] } \\
\text { cada [each] } \\
\text { rebutjar [to reject] } \\
\text { problema [problem] } \\
\text { adequada [adequate] } \\
\text { resposta [answer] }\end{array}$ & $\begin{array}{l}208.82 \\
203.31 \\
116 \\
113.73 \\
113.65 \\
89.38 \\
83.86\end{array}$ & $\begin{array}{l}\text { les respostes que s han experimentat } \\
\text { son de creacio de serveis de primera } \\
\text { acollida i centres residencials d estada } \\
\text { limitada, que donen una resposta mes } \\
\text { adequada a l atencio immediata que } \\
\text { requereixen els perfils i necessitats d } \\
\text { aquesta poblacio } \\
\text { en el temps transcorregut s ha eviden- } \\
\text { ciat una casuistica que aconsella } \\
\text { modificar aquesta legislacio }\end{array}$ \\
\hline 2 (green) & 61 & $\begin{array}{l}\text { pertinences [belongings] } \\
\text { participar [to participate] } \\
\text { decisió [decision] } \\
\text { introduir [to introduce] } \\
\text { posseir [to have] }\end{array}$ & $\begin{array}{l}104.84 \\
97.76 \\
91.57 \\
77.15 \\
77.15\end{array}$ & $\begin{array}{l}\text { introduir o posseir en el centre armes } \\
\text { o instruments especialment perillosos } \\
\text { i sostreure efectes del centre o } \\
\text { pertinences d'altres persones } \\
\text { esser escoltades en les decisions de } \\
\text { transcendencia, si han complert el } \\
\text { dotze anys, o si tenen judici suficient } \\
\text { si no els han complert }\end{array}$ \\
\hline 3 (blue) & 37 & $\begin{array}{l}\text { basic [basic] } \\
\text { fomentar [to foster] } \\
\text { propi [own] } \\
\text { eficacia [efficiency] } \\
\text { marginació [exclusion] }\end{array}$ & $\begin{array}{l}171.86 \\
147.03 \\
125.54 \\
123.06 \\
122.01\end{array}$ & $\begin{array}{l}\text { especialment, la xarxa basica de serveis } \\
\text { socials d atencio primaria ha de pro- } \\
\text { moure programes educatius i preventius } \\
\text { destinats a fomentar la capacitat de } \\
\text { critica, d autocontrol i el sentit de la } \\
\text { propia responsabilitat dels adolescent } \\
\text { amb conductes d alt risc social } \\
\text { son mesures preventives i educatives } \\
\text { (...) atenció en determinats centres } \\
\text { oberts, tallers i altres serveis comunita- } \\
\text { ris }\end{array}$ \\
\hline
\end{tabular}




\begin{tabular}{|l|l|l|l|l|}
\hline 4 (yellow) & 349 & menor [minor] & 33.5 & la ponencia recomana l adopció d un \\
& & llei [law] & 31.89 & text transaccional sobre les esmenes \\
& & article [article] & 29,17 & (...) \\
& & text [text] & 22.67 & afegeix un apartat a l'article $(. .$.$) de$ \\
& ciutadans [citizens] & 16.45 & la llei $37 / 1991$ del 30 de desembre, \\
& modificació [modification] & 16.42 & de proteccio de menors desamparats \\
& & & i de 1 adopcio, amb el text següent \\
\hline
\end{tabular}

Finally, results for Corpus D (questions-answers pairs) are shown in table 8 and figure 10 (which account for 68 percent of the variance). The largest classes as regards selected ECU are class 1 and 2, although there is a general equilibrium among classes. However, these more representative classes are the ones including the parliamentary formulae for question-answering. While class 1 refers to the general setting and to parliamentary actors in these sessions (speaker of the parliament, rules, formulation, article), class 2 refers to the actions carried out in this kind of sessions (basically, to answer, to respond, to express interest). But if we leave these two classes aside, what we find again is a strong superimposition of the three remaining classes $(3,4$, and 5) in the bottom-left part of the correspondence space. Although these classes present scant references to MEINA's irregular situation (class 3), and their origin (Magrib, Tangier in classes 3 and 5), they also represent questions regarding the department responsible for dealing with looking after these minors (class 4). Yet, again, the systematic overlapping of these classes denotes the lack of any significant discursive opposition in the texts representing the parliamentary questions to the Government and their respective answers.

Table 8. Statistic synthesis of questions-answers pairs (Corpus D)

\begin{tabular}{|c|c|c|c|c|}
\hline Class & ECU & Representative words & Chi square & Representative ECU \\
\hline \multirow[t]{5}{*}{1 (red) } & 64 & $\begin{array}{l}\text { pa la mesa del parlament } \\
\text { [to the speaker of the } \\
\text { parliament }]\end{array}$ & 126.59 & \multirow{5}{*}{$\begin{array}{l}\text { admissio a tramit: } \\
\text { a la mesa de el parlament diputat de } \\
\text { el grup de converg i unio, } \mathrm{d} \text { acord } \\
\text { amb el que s estableix a } 1 \text { article } 132 \\
\text { de el reglament de la cambra formu- } \\
\text { lar el seguent preguntar escrit a el } \\
\text { consell executiu }\end{array}$} \\
\hline & & tràmit [procedure] & 121.64 & \\
\hline & & $\begin{array}{l}\text { reglament de la cambra } \\
\text { [the rules of the } \\
\text { parliament }]\end{array}$ & 61.27 & \\
\hline & & formulació [formulation] & 61.27 & \\
\hline & & article [article] & 51.27 & \\
\hline
\end{tabular}




\begin{tabular}{|c|c|c|c|c|}
\hline 2 (green) & 51 & $\begin{array}{l}\text { resposta }[\text { answer }] \\
\text { per tal que }[\text { in order to }] \\
\text { saber }[\text { to know] } \\
\text { interessar }[\text { to have } \\
\text { interest }] \\
\text { contestar }[\text { to respond }]\end{array}$ & $\begin{array}{l}37.74 \\
33.72 \\
31.33 \\
31.33 \\
\\
29.88\end{array}$ & $\begin{array}{l}\text { es per aquest motiu fonamental que el } \\
\text { diputat sotasignat preguntar i pregun- } \\
\text { tar ara: a quant infant, adolescent o } \\
\text { jove } d \text { origen marroqui haver benefi- } \\
\text { ciar l acord o pre acord, o protocol, } \\
\text { que anar subscriure } 1 \text { anterior conse- } \\
\text { llera de justicia en el seu viatge a el } \\
\text { marroc? } \\
\text { interessar saber a aquest diputat i a } \\
\text { el seu grup parlamentari: te coneixe- } \\
\text { ment el consell executiu de el fet } \\
\text { denunciar per el federacio d associa- } \\
\text { cions de veins de barcelona en relacio } \\
\text { amb el pagament de responsable de el } \\
\text { govern de bitllet d autocar a jove } \\
\text { immigrant perque viatjar a d altres } \\
\text { comunitat autonomes? }\end{array}$ \\
\hline 3 (blue) & 41 & $\begin{array}{l}\text { països }[\text { countries }] \\
\text { irregular [irregular] } \\
\text { atànyer [ fig. to belong] } \\
\text { quan }[\text { when }] \\
\text { persona }[\text { person }]\end{array}$ & $\begin{array}{l}35.68 \\
30.46 \\
27 \\
25.77 \\
25.58\end{array}$ & $\begin{array}{l}\text { aquest dada posar de manifest princi- } \\
\text { palment } 1 \text { elevadissim nombre de rein- } \\
\text { cidencies pel que fa a el presencia de } \\
\text { menor immigrant a el dependencies de } \\
\text { el dgai. en relacio amb el procedencia } \\
\text { de el menor immigrant atànyer per el } \\
\text { dgai, actualment, el } 69 \text { procedir de } \\
\text { paisos de el magrib, el } 12 \text {. }\end{array}$ \\
\hline 4 (yellow) & 31 & $\begin{array}{l}\text { direccio general } \\
\text { [subdepartment }] \\
\text { adolescencia }[\text { adolescence }] \\
\text { infancia }[\text { childhood] } \\
\text { acollir }[\text { to take care }] \\
\text { recurs [resource] }\end{array}$ & $\begin{array}{l}46.91 \\
46.18 \\
40.91 \\
32.61 \\
24.53\end{array}$ & $\begin{array}{l}\text { el departament de benestar i familia, } \\
\text { a traves de el direccio general d aten- } \\
\text { cio a el infancia i } 1 \text { adolescencia, } \\
\text { dgaia, aten el menor estranger mitjan- } \\
\text { cant programa i servei especifics i a- } \\
\text { traves, tambe, } \\
\text { quin haver ser } 1 \text { evolucio de el nom- } \\
\text { bre de menor estranger atànyer el } \\
\text { darrer } 10 \text { any a cada un de el centre d } \\
\text { acollida i el centre residencials, crae, } \\
\text { dependent de el direccio general d } \\
\text { atencio a el infancia i adolescencia, } \\
\text { de gestio propia o aliena? }\end{array}$ \\
\hline 5 (purple) & 57 & $\begin{array}{l}\text { entitat [entity] } \\
\text { banda [ } \text { gang] } \\
\text { curs [course }] \\
\text { dur a terme [to carry out] } \\
\text { tanger [Tangier] }\end{array}$ & $\begin{array}{l}25.35 \\
23.64 \\
23.64 \\
23.64 \\
16.75\end{array}$ & $\begin{array}{l}\text { estar acollir en centre residencials } \\
\text { dependent de el dgai. per a el realitza- } \\
\text { cio d aquest projecte, } 1 \text { icaa anar sig- } \\
\text { nar conveni amb } 2 \text { institució } \\
\text { col-laboradores d integracio familiar, } \\
\text { com son } 1 \text { institut de reinsercio social, } \\
\text { ires, i el creu roja catalunya, } \\
\text { aquest model d intervencio es com- }\end{array}$ \\
\hline
\end{tabular}




\begin{tabular}{|l|l|l|}
\hline & & $\begin{array}{l}\text { plementa amb el posat en marxa de el } \\
\text { programa barcelona tanger, promoure } \\
\text { conjuntament amb el secretaria d } \\
\text { immigracio. aquest programa establir } \\
\text { 3 eix d actuacio: l establiment d un } \\
\text { centre d acolliment residencial a l } \\
\text { area de tanger; }\end{array}$ \\
\hline
\end{tabular}

Figure 10. Correspondence analysis of questions-answers pairs (Corpus D)

\section{Concluding Remarks}

Although for some time the media coverage of the MEINA phenomenon could have contributed to «switching on» the mechanics of the «issue-attention cycle» (Downs, 1972; Peters \& Hogwood, 1985), this problem might hardly be understood as having gone beyond the pre-problem stage - i.e., the stage before the problem receives certain amount of attention allocation from political elites (Jones \& Baumgartner, 2004). Rather, we observe that the administrative rearrangements considered so far have taken place without a corresponding substantial debate in the parliamentary settings. Or, to put it differently, the MEINA issue might not have captured much public attention, although specific research on this question has not been completed yet. 
As our subtitle suggests, we compare this parliamentarian discursive action to an empty set. The empty set is not equivalent to «nothing», but it is a set with no elements inside it. In our case, the set of parliamentary activities covering the issue of unaccompanied children contains no elements to ground a substantial political debate around it. Or, in other words, while we have seen that decisions have been made on the matter, they do not seem to have been triggered or followed by particularly intense political debate in parliamentary premises.

The major trend of parliamentary discourse regarding «unaccompanied children» - and the one that is of main interest here - suggests the absence of clearly opposed political views regarding the issue. In other words, given that the political debate on MEINA had not taken place through an active parliamentary rulemaking activity, we expected it to have occurred in other ways through parliamentary action, such as questions to the government or ordinary sessions devoted to MEINA or related issues in frameworks other than rulemaking.

Our observation, nonetheless, is that no opposed discourse views can be traced in any of the documents analyzed, provided that the MEINA matter is not a relevant dimension in those political debates. Rather, a vague and discreet consensus on the matter seems to prevail in every text considered. For that reason, if we take the metaphor further, we may qualify the parliamentary pronouncements regarding children immigration as «vacuously true» statements, since the majority of parliamentary groups tend to hold them true by consensus without being necessarily related to the administrative reforms running parallel to them.

This is especially the case with two of the four corpora analyzed: reports of the Ombudsman to the Catalan Parliament, and parliamentary motions and resolutions. Both the reports and the motions/resolutions are rather formal parliamentary activities whose main objective is, on the one hand, to acknowledge the role of the Ombudsman and, on the other, to adopt a general consensus on a specific matter. But the consensual view is also apparent in the two debates involving the approval of the 8/2002 Act of May $27^{\text {th }}$ and in the written pairs of parliamentary questions-answers.

The results, moreover, suggest that when some discussion is achieved on the social dimensions of the problem, such a discussion is overlapped with technical difficulties, such as funding or certain departmental organization problems, which iverts the «image» of that policy problem (Baumgartner \& Jones, 1991) towards a technical rather than social nature or definition. ${ }^{20}$

20. Howlett (1997) provides an empirical revision of Downs' (1972), Baumgartner and Jones' (1991), and Kingdon's (1984) approaches for future research in this field. Stuart Soroka (1999) provides a very useful comment on Howlett's work. For comments and methodological proposals on the Issue-Attention Cycle, see also Peters \& Hogwood (1985) and Henry \& Gordon (2001). 
In conclusion, the MEINA phenomenon languishes in a pre-political stage though not in a pre-decisional one, as attention and resources have been clearly allocated at the administrative level, but not at the level of the political discourse. At least, these results suggest that decisions do not seem to be the outcome of an open and deep political debate. A plain explanation for it may be that as far as no public demand (in form of social alarm or a lasting public debate) on this issue is identified, no (open) political action is taken in so far the elites do not perceive the problem as being part of the «public agenda» (Jones \& Baumgartner 2004). Yet, as far as democracy is concerned, this situation may raise some serious doubts about the Catalan welfare democratic system.

In our opinion, further research on this issue should cover, at least, (1) a thorough exploration of the population directly affected; (2) a serious assessment of the relationship (if any) between issue salience processes in the media and in policy makers; (3) an inquiry of issue definition carried out by different public actors; (4) the analysis of the decision-making flow and instances of strategic behavior taking place in this agenda-setting situation, which might raise, for instance, questions about discretionary behavior in some stages of the political and administrative hierarchy, in the absence of an open and thorough political debate ${ }^{21}$ and finally (5) an empirical evaluation of the key challenges to institutional performance and to the quality and operation of Catalan (and Spanish) governance structures that this issue posits.

\section{Acknowledgements}

We would like to thank M. Antònia Martí from CLIC (Centre de Llenguatge i Computació, http://clic.ub.edu/) and Montserrat Nofre from STeL (Servei de Tecnologia Lingüística, http://www.ub.edu/stel/stel.htm), both from the University of Barcelona, for their collaboration and work on the text corpora. We are also grateful to Violeta Quiroga, who kindly granted permission to reproduce two tables from her doctoral dissertation. Finally, we would like to thank the three anonymous reviewers that gave us significant comments and recommendations that helped to improve this work.

\section{Works Cited}

AJA, E.; D. Moya (dirs.) (2003): Els menors immigrants en desamparament a Catalunya, Estudis 9, Barcelona, Fundació Carles Pi i Sunyer.

21. In this sense, Kingdon's work (1984) would seem very fruitful. 
BAAYEN, R. H. (2008): Analyzing Linguistic Data. A Practical Introduction to Statistics, New York, Cambridge University Press.

BAstin, G. (2002): «Note sur la méthode Alceste: mondes sociaux et mondes lexicaux», MELISSA, November 28, <http://www.melissa.ens-cachan.fr/ spip.php?article200>.

Bailey, A.; Ch. Schonhardt-Bailey (2008): «Does deliberation matter in FOMC monetary policymaking? The Volcker Revolution of 1979», Political Analysis, 16(4): 372-403.

Bara, J.; A. Weale; A. Bicquelet (2007): «Analysing parliamentary debate with computer assistance», Swiss Political Science Review, 13(4): 577-605.

Baumgartner, F. R.; B. D. JoneS (1991): «Agenda dynamics and policy subsystems», The Journal of Politics, 53: 1044-74.

BenoIT, K.; M. LAVER (2007): «Benchmarks for text analysis: a response to Budge and Pennings», Electoral Studies, 26: 130-135.

Benoit, K.; M. Laver; S. Mikhaylov (2009): «Treating words as data with error: Uncertainty in text statements of policy positions» American Journal of Political Science, 53(2): 495-513.

Budge, I.; P. Pennings (2007 $a$ ): «Do they work? Validating computerised estimates against policy series», Electoral Studies, 26: 121-129.

- (2007 b): «Missing the message and shooting the messenger: Benoit and Laver's 'response'», Electoral Studies, 26: 136-141.

Capdevila, M.; M. Ferrer (2003): «Els menors estrangers indocumentats no acompanyats (MEINA)», unpublished document, Barcelona, Centre d'Estudis Jurídics i Formació Especialitzada, (see a summary of the report in <http://www.gencat.net/justicia/doc/doc_33546445_1.pdf>).

Carmines, E. G.; R. A. Zeller (1979): Reliability and validity assessment, Series on quantitative applications in the social sciences, Thousand Oaks, Sage Publications.

Carmona, J.; S. Cervell; L. Márquez; M. A. Martí; L. Padró; R. Placer; H. Rodríguez; M. Taulé; J. Turmo (1998): «An environment for morphosyntactic processing of unrestricted Spanish text» in Proceedings of the First Conference on Language Resources and Evaluation, Granada. 915-922.

Comas, M.; V. Quiroga (2005): Menors que emigren sols del Marroc a Catalunya, Polítiques 51, Barcelona, Fundació Jaume Bofill/Editorial Mediterrània.

Defensor del Pueblo (2005): «Informe sobre asistencia jurídica a los extranjeros en España», <http://www.defensordelpueblo.es/informes2.asp>.

Defensories De L'Estat (2006): «Declaració de les Defensories del Poble sobre les responsabilitats de les administracions públiques pel que fa als menors no acompanyats», <http://www.sindic.cat/ficheros/informes/43_ Leon\%20menorscatala.pdf $>$. 
General Directorate of Care for Children and Adolescents (2006): «Guia bàsica», <http://www.gencat.net/benestar/dgaia/>, updated version available at <http://www20.gencat.cat/docs/dasc/03Ambits\%20tematics/ 07Infanciaiadolescencia/Recursos_professionals/Pdf/DGAIA_guia_2009_ EN_low.pdf>.

GreenaCre, M. J. (1993): Correspondence Analysis in Practice, London, Academic Press.

Henry, G. T.; C. S. Gordon (2001): «Tracking issue attention», The Public Opinion Quarterly, 65(2): 157-177.

HowleTt, M. (1997): «Issue-attention and punctuated equilibria models reconsidered: An empirical examination of the dynamics of agenda-setting in Canada», Canadian Journal of Political Science, 30(1): 3-29.

Informe CONRED (2005): «Rutas de pequeños sueños. Los menores migrantes no acompañados en Europa», investigadora principal Dra. Violeta QuIROGA, Fundació Pere Tarrés, <http://www.peretarres.org/daphneconred/ estudi/informe.html>.

Jones, B. D.; F. R. BAumgartner (2004): «Representation and agenda setting», The Policy Studies Journal, 32(1): 1-24.

Kingdon, J. W. (1984): Agendas, Alternatives, and Public Policies, New York, Harper Collins.

Klingemann, H.D.; A. Volkens; J. L. Bara; I. Budge; M. D. MCDonald (2006): Mapping Policy Preferences II: Estimates for Parties, Electors, and Governments in Eastern Europe, European Union, and OECD 1990-2003, Oxford, Oxford University Press.

KLÜVER, H. (2009): «Measuring interest group influence using quantitative text analysis», European Union Politics, 10(4): 535-549.

KRIPPENDORFF, K. (2004): Content analysis: An introduction to its methodology 2nd ed., Thousand Oaks, Sage Publications.

Lasswell, H. D.; LeITeS, N.; et al. (1949): Language of politics: Studies in quantitative semantics, New York, George W. Stewart Publisher.

LAVER, M.; K. BenoIT; J. GARRY (2003): «Extracting policy positions from political texts using words as data», American Political Science Review, 97(2): 311-331.

Lowe, W. (2008): «Understanding wordscores», Political Analysis, 16(4): 356371 .

MagnetTe, P. (2003): «Between parliamentary control and the rule of law: The political role of the ombudsman in the european union», Journal of European Public Policy, 10(5): 677-694.

Murtagh, F. (2005): Correspondence Analysis and Data Coding with Java and $R$, Boca Raton, Chapman \& Hall/CRC.

Neuendorf, K. A. (2002): The Content Analysis Guidebook, Thousand Oaks, Sage Publications. 
Padró, Ll.; M. Collado; S. Reese; M. Lloberes; I. Castellón (2010): «FreeLing 2.1: Five Years of Open-Source Language Processing Tools», Proceedings of 7th Language Resources and Evaluation Conference (LREC 2010), ELRA, May, 2010, La Valletta. <http://nlp.lsi.upc.edu/freeling>.

Peters, G.; B. W. Hogwood (1985): «In search of the issue-attention cycle» The Journal of Politics, 47(1): 238-253.

QuirogA, V. (2003): Els petits harraga, menors immigrats irregulars no acompanyats d'origen marroquí a Catalunya, doctoral dissertation, Universitat Rovira i Virgili, <http://www.tesisenxarxa.net/>.

Reinert, M. (1986): «Présentation du logiciel ALCESTE à l'aide d'un exemple», Psychologie et Education, X(2): 58-73.

- (1987): «Un logiciel d'analyse lexicale (ALCESTE)» Cahiers Analyse des Données, 4: 471-484.

- (2003): «Le rôle de la répétition dans la représentation du sens et son approche statistique par la méthode ALCESTE «, Semiotica, 147(1/4): 389-420.

Ruxton, S. (2003): «Separated children and EU asylum and immigration policy», Save the Children Denmark.

SCEP (Separated Children in Europe Programme) (2004): «Statement of good practice».

SchonhardT-Bailey, Ch. (2005): «Measuring ideas more effectively: an analysis of Bush and Kerry's national security speeches», PS: Political Science \& Politics, 38(4): 701-711.

SementKo, H. A.; P. M. VAlkenburg (2000): «Framing European politics: A content analysis of press and television news», Journal of Communication, 93, Spring:109.

Síndic de Greuges de Catalunya (1999): «Informe elevat al Parlament de Catalunya, corresponent a l'any 1999», <http://www.sindic.cat/cat/ inform_estudis.asp $>$.

- (2006): «La situació dels menors immigrats sols», <http://www.sindic.cat/ cat/inform_estudis.asp $>$.

Slapin, J. B.; S. O. Proksch (2008): «A scaling model for estimating timeseries party positions from texts» American Journal of Political Science, 52(3): 705-722.

SoroKA, S. (1999): «Policy agenda-setting theory revisited: A critique of Howlett on Downs, Baumgartner and Jones, and Kingdon», Canadian Journal of Political Science, 32(4): 763-772.

SOS RACISMo (2005): Menores en las fronteras: de los retornos efectuados sin garantías a menores marroquies y de los malos tratos sufridos, $<$ <ttp://www.sosracisme.org/reflexions/pdfs/menores_retornados.pdf>. 
UNHCR (1997): «Guidelines on policies and procedures in dealing with unaccompanied children seeking asylum», <http://www.unhcr.org/publ/ PUBL/3d4f91cf4.pdf>. 